\title{
Pengaruh Perbedaan Dataran terhadap Profil Litter Ayam Broiler yang Dipelihara di Kandang Closed House
}

\section{Effect of Differences in Plains on Litter Profiles of Broiler Chickens which is Cared for in Closed House Stables}

\author{
C. S. Utama*, F. Wahyono, dan M. F. Haidar \\ Fakultas Peternakan dan Pertanian, Universitas Diponegoro, Semarang \\ Jl. Prof. Soedarto No.50275, Tembalang, Kec. Tembalang, Kota Semarang, Jawa Tengah 50275 - \\ Indonesia \\ *Corresponding E-mail: cahyasetyautama@gmail.com \\ (Diterima: 26 Oktober 2020; Disetujui: 28 Januari 2021)
}

\begin{abstract}
ABSTRAK
Pemeliharaan ayam broiler dipengaruhi oleh suhu, kelembaban, letak kandang, kualitas pakan dan manajemen pemeliharaan. Perbedaan dataran memiliki makroklimat (temperatur, kelembaban, kecepatan angin dan radiasi matahari) yang berbeda dan berpengaruh pada mikroklimat kandang closed house. Mikroklimat yang berbeda akan mengakibatkan perbedaan ketebalan litter dan berakibat pada performa produksi ayam broiler. Penelitian ini bertujuan untuk mengkaji pengaruh perbedaan dataran terhadap profil litter yang meliputi ketebalan litter, persentase litter, kandungan telur cacing dan jenis cacing pada litter ayam broiler yang dipelihara dengan sistem perkandangan closed house. Penelitian menggunakan rancangan acak lengkap (RAL) dengan 3 perlakuan dan 5 ulangan. Perlakuan penelitian terdiri dari T1 (kandang closed house di ketinggian $\leq 100$ meter di atas permukaan laut (mdpl)), T2 (kandang closed house di ketinggian 100 - 300 mdpl) dan T3 (kandang closed house di ketinggian 300 - 500 mdpl). Metode yang digunakan yaitu purposive random sampling pada beberapa titik di dalam kandang yang mewakili luas kandang untuk mengukur ketebalan dan persentase litter, penentuan jumlah telur cacing dengan metode apung (Flotation method) dan jenis telur cacing dengan metode Mc. Master. Hasil penelitian menunjukan perbedaan dataran berpengaruh nyata $(\mathrm{P}<0,05)$ terhadap ketebalan litter, namun tidak berpengaruh nyata terhadap persentase litter dan kandungan telur cacing. Hasil penelitian dapat disimpulkan bahwa perbedaan ketinggian dataran mempengaruhi ketebalan litter pada kandang closed house sedangkan telur cacing tidak ditemukan.
\end{abstract}

Kata kunci: ayam broiler, closed house, dataran, litter, telur cacing

\section{ABSTRACT}

Broiler maintenance is influenced by temperature, humidity, house location, feed quality, and maintenance management. Different plains have different macroclimates (temperature, humidity, wind speed, and solar radiation) and affect the microclimate of closed house housing. Different microclimates will result in differences in litter thickness and result in broiler production performance. This research examines the effect of different terrain on litter profiles, including litter thickness, litter percentage, worm egg content, and worm species in broiler chicken litter with a closed house housing system. The research design used was a completely randomized design (CRD) with three treatments and five replications. The treatment in this Study was T1 closed-house cage at an altitude of $\leq 100$ meters from sea level, T2 closedhouse cage at an altitude of $100-300 \mathrm{masl}$, and T3 closed-house cage at an altitude of $300-500$ masl. The method used was purposive random sampling at several points in the cage, which represents the area of the cage to measure the thickness and percentage of litter, the flotation method to determine the number of worm eggs, and the Mc. Master to determine the type of worm eggs. The results showed that the difference in terrain had a significant effect $(P<0.05)$ on litter thickness but did not significantly affect the percentage 
of litter and content of worm eggs. The results showed that the difference in land height affected litter thickness in closed house cages, while worm eggs were not found.

Keywords: broiler chickens, closed house, litter, plains, worm eggs

\section{PENDAHULUAN}

Industri peternakan unggas semakin meningkat, baik segi kuantitas dan kualitas seiring dengan perkembangan zaman. Hal tersebut diakibatkan oleh meningkatnya kebutuhan akan produk unggas seperti daging dan telur. Bibit dan manajemen pemeliharaan sangat mempengaruhi produktivitas unggas (Saputra et al., 2015). Keadaan makroklimat dan mikroklimat pada kandang yang tidak sesuai akan mengakibatkan ternak stres dan berdampak pada penurunan produksi. Ketinggian wilayah kandang juga berpengaruh terhadap performa ayam broiler (Qurniawan et al., 2016). Perbedaan dataran berpengaruh terhadap makroklimat dan mikroklimat. Suhu lingkungan yang ekstrim menyebabkan ayam mengalami cekaman sehingga berpengaruh pada pertambahan bobot badan, konversi pakan, kesehatan dan tingkat mortalitas (Dharmawan et al., 2016). Ketinggian tempat $>700$ mdpl mempengaruhi status fisiologi, performans produksi, konsumsi air minum, bobot badan akhir dan FCR (Marom et al., 2017). Semakin tinggi suatu wilayah maka akan mengakibatkan penurunan suhu wilayah.

Suhu dan kelembaban pada kandang closed house juga dipengaruhi oleh faktor makro dan mikro klimat meskipun dapat diatur sesuai dengan keinginan (Dewanti et al., 2014). Semakin tinggi suatu wilayah, mengakibatkan penurunan suhu wilayah. Suhu yang dibutuhkan untuk ayam broiler berproduksi secara optimal berkisar $18-21^{\circ} \mathrm{C}$ (Marom et al., 2017).

Manajemen pemeliharaan ayam broiler, sangat membutuhkan litter sebagai alas dan penghangat bagi ayam broiler. Kualitas litter sangat menentukan keberhasilan pemeliharaan ayam broiler (Muharlien et al., 2011). Litter biasanya berasal dari sekam, serbuk kayu atau jerami. Semakin bagus kualitas litter, maka performance ayam broiler semakin baik (Herawati dan Winarso, 2016; Najibulloh et al., 2020). Litter yang buruk dapat menjadi media tumbuh bagi endoparasit maupun eksoparasit parasit.

Parasit tersebut dapat menurunkan produktivitas ternak (Silaban et al., 2018). Parasit jenis endoparasit merupakan parasite yang hidup pada lingkungan dalam induk inangnya. Jenis endoparasit antara lain cacing, bakteri dan virus. Litter ayam broiler dapat mengandung endoparasit seperti telur cacing yang berasal dari ekskreta ayam yang bercampur dengan litter (Pradana et al., 2015). Telur cacing yang menginfeksi ternak maka akan berdampak pada penurunan produktivitas hingga kematian ayam broiler (Moenek dan Oematan, 2017).

Tujuan penelitian yaitu mengkaji pengaruh perbedaan dataran terhadap profil litter yang meliputi ketebalan litter, presentase litter, kandungan telur cacing dan jenis cacing pada litter ayam broiler yang dipelihara dengan sistem perkandangan closed house. Manfaat penelitian yaitu dapat menentukan profil litter meliputi ketebalan litter, presentasi litter, kandungan telur cacing dan jenis telur cacing yang tepat pada setiap ketinggian dataran sehingga memperoleh performa ayam broiler yang maksimal.

\section{METODE}

\section{Materi Penelitian}

Bahan yang digunakan yaitu litter pada 15 kandang closed house mitra PT. Citra Unggas Lestari yang berlokasi di Kabupaten Demak dengan ketinggian $\leq 100 \mathrm{mdpl}$, Kota Semarang dengan ketinggian $100-300$ mdpl dan Kabupaten Kendal dengan ketinggian 300 - 500 mdpl, aquadest dan larutan $\mathrm{NaCl}$. Alat yang digunakan yaitu penggaris, 
kantong plastik, sarung tangan, botol pot plastik, mortar, saringan, tabung sentrifuge, volume $15 \mathrm{ml}$, kaca preparat, pipet pasteur (pipet tetes), kaca penutup, Mc. Master dan mikroskop trinokuler.

\section{Metode Penelitian}

Penelitian menggunakan rancangan acak lengkap (RAL) dengan 3 perlakuan dan 5 ulangan. Perlakuan terdiri dari T1 (kandang closed house di ketinggian $\leq 100 \mathrm{mdpl}$ ), T2 (kandang closed house di ketinggian 100 300 mdpl) dan T3 (kandang closed house di ketinggian 300 - $500 \mathrm{mdpl}$ ).

\section{Pengukuran Parameter}

\section{Ketebalan Litter}

Pengambilan sampel litter dilakukan setelah proses pemanenan ayam broiler. Pengukuran ketebalan litter dilakukan dengan cara sampel litter diambil secara acak dan menyebar pada setiap kandang yang mewakili luasan kandang (purposive random sampling). Setelah diketahui titik sampel litter tersebut diukur ketebalannya dengan menggunakan penggaris diukur dari dasar lantai sampai ketinggian litter. Hasil pengukuran dicatat pada lembar kerja dan ditabulasi menjadi data penelitian.

\section{Persentase Litter}

Pengukuran persentase litter dilakukan dengan cara sampel litter yang telah dikumpulkan pada setiap kandang ditimbang bobot awal terlebih dahulu, kemudian sekam dan manure pada litter dipisahkan dengan menggunakan saringan. Hasil penyaringan diletakkan pada wadah yang berbeda kemudian ditimbang hasil sekam dan manure. Kemudian dihitung persentase sekam dan manure dengan rumus:

\section{Bobot hasil pemisahan (gr) Bobot awal litter (gr)}

\section{Pengujian Kandungan Telur Cacing}

Identifikasi kandungan telur cacing dilakukan secara kualitatif (metode apung / Flotation methode) (Silaban et al., 2018) dan kuantitatif (metode Mc. Master) (Ananda et al., 2017).

Identifikasi dengan metode apung (Flotation methode) berfungsi mengetahui jenis telur cacing (Loliwu dan Thalib, 2012). 2 gram litter diletakkan pada botol pot plastik, kemudian ditambahkan garam jenuh $30 \mathrm{ml}$, diaduk hingga homogen. Campuran yang telah homogen kemudian disaring, hasil saringan dimasukkan pada tabung sentrifuge sebanyak $15 \mathrm{ml}$, kemudian disentrifuge selama 5 menit dengan kecepatan $1500 \mathrm{rpm}$. Tambahkan garam jenuh hingga permukaan cairan pada posisi tepat di atas permukaan tabung. Letakkan kaca penutup pada atas tabung, kemudian diamkan selama 5 menit. Setelah itu kaca penutup diletakkan didalam kaca preparat. Pengamatan morfologi telur cacing menggunakan mikroskop sedangkan identifikasi jenis cacing dilakukan menggunakan manual book dan buku identifikasi.

Pengamatan kuantitas telur cacing dengan metode Mc Master (Ananda, et al., 2017). 2 gram litter ditimbang, kemudian dimasukkan pada botol pot plastik, ditambahkan $28 \mathrm{ml}$ aquades, campuran diaduk sampai homogen. Larutan yang telah homogen diambil $1 \mathrm{ml}$ dan diletakkan pada tabung sentrifuge, kemudian tambahkan $1 \mathrm{ml} \mathrm{NaCl}$. Campuran tersebut diteteskan pada kamar Mc. Master kemudian diamkan selama 20 menit. Amati kamar Mc. Master dengan mikroskop serta difokuskan pada setiap kolom kamar Mc. Master. Jumlah telur hasil pengamatan pada setiap kolom dihitung dengan menggunakan rumus:

$$
\mathrm{EPG}=2 \mathrm{n} \times 50
$$

Keterangan:

$\mathrm{n} \quad$ : Jumlah telur cacing terhitung pada kamar hitung

EPG : Egg per gram (telur cacing per gram)

\section{Analisis Data}

Data yang diperoleh kemudian dianalisis dengan menggunakan uji Analysis of Variance (ANOVA) dan jika terdapat pengaruh nyata, dilanjutkan dengan uji Duncan's Multiple Range Test (DMRT) 
Tabel 1. Pengaruh Perbedaan Ketinggian Dataran terhadap Ketebalan Litter Ayam Broiler yang Dipelihara pada Sistem Perkandangan Closed House

\begin{tabular}{lcccccc}
\hline \multirow{2}{*}{ Perlakuan } & \multicolumn{5}{c}{ Ulangan $(\mathrm{cm})$} & \multirow{2}{*}{ Rataan } \\
\cline { 2 - 5 } & U1 & U2 & U3 & U4 & U5 & \\
\hline T1 & 6,70 & 5,14 & 4,78 & 6,27 & 6,27 & $6,27^{\mathrm{b}} \pm 1,25$ \\
T2 & 7,50 & 6,95 & 6,44 & 6,93 & 6,93 & $6,52^{\mathrm{b}} \pm 0,38$ \\
T3 & 10,20 & 7,80 & 7,59 & 7,29 & 7,18 & $8,01^{\mathrm{a}} \pm 0,82$ \\
\hline
\end{tabular}

Keterangan: Supersrkrip berbeda menunjukan hasil perbedaan nyata $(\mathrm{P} \leq 0,05)$.

dengan taraf kepercayaan 5\%.

\section{HASIL DAN PEMBAHASAN}

Perbedaan ketinggian dataran berpengaruh terhadap suhu dan kelembaban suatu wilayah. Semakin tinggi dataran, maka semakin rendah suhu dataran tersebut. Manajemen pemeliharaan ayam broiler perlu memperhatikan kondisi suhu serta kelembaban untuk mencapai performa terbaik (Qurniawan et al., 2016). Berbagai cara untuk mencapai comfort zone bagi ayam broiler antara lain penambahan litter sebagai alas untuk membuat ayam broiler lebih hangat (Muharlien et al., 2011). Suhu yang rendah pada suatu dataran akan membuat litter lebih tebal daripada dikondisi suhu yang tinggi.

Hasil pengamatan menunjukkan perlakuan ketinggian dataran yang berbeda berpengaruh nyata $(\mathrm{P} \leq 0,05)$ terhadap ketebalan litter. Tabel 1. menunjukkan bahwa rata-rata ketebalan litter yaitu $6,27-8,01 \mathrm{~cm}$. Wahyudi et al. (2010) menyatakan bahwa ketebalan litter di awal periode pemeliharaan berkisar 5-8 cm, akan mengalami penambahan selama periode pemeliharaan berjalan. Perlakuan T1 menunjukan hasil yang berbeda nyata terhadap perlakuan T3. Sedangkan perlakuan T2 menunjukan hasil yang tidak berbeda nyata dengan T1 akan tetapi berbeda nyata dengan T3. Ketinggian dataran termasuk ke dalam faktor makroklimat kandang yang berhubungan dengan kondisi mikroklimat kandang (Endraswati et al., 2019). Ketika suhu sekitar kandang rendah, maka dibutuhkan alas kandang yang tebal untuk membantu ternak mencapai comfort zone. Olivia et al. (2015) menyatakan penggunaan litter kandang memperhatikan faktor suhu dan kelembaban kandang.

Ketebalan litter pada setiap kandang dipengaruhi oleh beberapa faktor antara lain manajemen pemeliharaan, jenis ayam dan lingkungan kandang yang mencakup ketinggian lokasi, suhu dan kelembaban. Selama proses pemeliharaan dilakukan pergantian dan penambahan litter untuk mengurangi ammonia dalam kandang. Kadar ammonia yang tinggi di dalam kandang dapat menjadi awal munculnya penyakit pada ayam broiler (Marang et al., 2019). Litter dapat berkontribusi menjadi sumber panas bagi ayam broiler. Semakin tebal litter yang digunakan maka, akan menghasilkan panas lebih tinggi (Olivia et al., 2015).

\section{Persentase Litter}

Litter merupakan alas yang digunakan pada pemeliharaan ayam broiler sekaligus berfungsi sebagai penghangat bagi ayam broiler. Pada masa akhir pemeliharaan ayam broiler, litter yang berbahan dasar sekam akan bercampur dengan manure ayam broiler yang dihasilkan pada saat pemeliharaan (Herawati dan Winarso, 2016). Manure ayam broiler mengandung bahan organik dan anorganik serta memiliki kandungan amonia tinggi yang berasal dari saluran pencernaannya (Ibrahim dan Allaily, 2012).

Hasil analisis menunjukan bahwa perbedaan ketinggian dataran tidak mempengaruhi persentase litter. Tabel 2 . menunjukan hasil perlakuan ketinggian $\mathrm{T} 1$, T2 dan T3 menunjukan hasil tidak berbeda 
JPI Vol. 23 (2): 115-121

Tabel 2. Pengaruh Perbedaan Ketinggian Dataran terhadap Persentase Litter Ayam Broiler yang Dipelihara pada Sistem Perkandangan Closed House

\begin{tabular}{llcccccc}
\hline \multirow{2}{*}{ Perlakuan } & \multicolumn{5}{c}{ Ulangan } & \multirow{2}{*}{ Rataan } \\
\cline { 2 - 6 } & U1 & U2 & U3 & U4 & U5 & \\
\hline \multirow{2}{*}{ T1 } & Sekam (\%) & 27,68 & 21,58 & 48,52 & 52,68 & 41,40 & $38,37 \pm 10,88$ \\
& Manure (\%) & 71,32 & 78,42 & 51,48 & 47,32 & 58,60 & $61,43 \pm 10,88$ \\
\multirow{2}{*}{ T2 } & Sekam (\%) & 26,36 & 27,82 & 43,89 & 30,21 & 24,14 & $30,48 \pm 7,81$ \\
& Manure (\%) & 73,64 & 72,18 & 56,11 & 69,79 & 75,86 & $69.52 \pm 7,81$ \\
\multirow{2}{*}{ T3 } & Sekam (\%) & 40,74 & 54,79 & 31,55 & 26,60 & 42,55 & $39,24 \pm 13,35$ \\
& Manure (\%) & 59,26 & 45,21 & 68,45 & 73,40 & 57,45 & $60,75 \pm 13,16$ \\
\hline
\end{tabular}

nyata. Persentase litter terdiri dari campuran dari sekam dan manure ayam broiler. Hasil rata-rata persentase sekam berkisar 30,48 - 39,24\% dan persentase manure berkisar $60,75-69,53 \%$. Semakin tinggi persentase sekam maka semakin tinggi juga kandungan serat kasarnya (SK). Hal itu dikarenakan sekam memiliki kadar SK berkisar 37,33\% (Amrullah et al., 2019). Persentase manure yang semakin tinggi akan mempengaruhi kandungan protein kasar litter tersebut. Hal ini disebabkan kandungan ammonia pada manure yang tinggi. Saputra et al. (2020) menyatakan peningkatan kandungan nitrogen ekskreta akan diikuti dengan peningkatan kadar amonia pada litter.

Persentase Litter dapat dipengaruhi oleh faktor manajemen pemeliharaan yang meliputi pembersihan litter secara berkala, sanitasi kandang, konsumsi pakan, kondisi kandang dan kondisi ayam. Fatmaningsih et al., (2016) menambahkan ekskreta ayam pedaging lebih banyak dikarenakan konsumsi pakan yang lebih tinggi. Ketinggian wilayah sangat mempengaruhi kelembaban kandang. Litter kandang yang basah akan berdampak buruk bagi ternak sehingga harus dilakukan pergantian litter (Olivia et al., 2015). Pergantian litter ayam broiler pada periode pemeliharaan harus memperhatikan kondisi litter sehingga tidak berdampak pada performa ayam broiler (Muharlien et al., 2011).

\section{Telur Cacing}

Telur cacing merupakan jenis endoparasit yang sering ditemukan pada litter (Herawati dan Winarso, 2016). Kandungan telur cacing pada litter disebabkan oleh manajemen pemeliharaan yang buruk maupun dari ekskreta ayam broiler. Kondisi litter yang lembab menjadi tempat berkembangbiaknya telur cacing. Kandungan telur cacing yang tinggi dapat menginfeksi ayam broiler dan akan menurunkan performa ayam broiler (Silaban et al., 2018).

Berdasarkan hasil analisis kandungan telur cacing, pada ke 15 sampel litter ayam broiler tidak ditemukan kandungan telur cacing. Ketinggian suatu wilayah kandang tidak mempengaruhi kandungan telur cacing pada litter ayam broiler. Pertumbuhan telur cacing terjadi pada suhu optimum berkisar $25-30{ }^{\circ} \mathrm{C}$ (Resnhaleksmana, 2014). Suhu rata-rata pada ketiga ketinggian wilayah kandang berkisar $25-33^{\circ} \mathrm{C}$, akan tetapi tidak ada kandungan telur cacing. Hal ini mengindikasikan bahwa ketebalan litter tidak menjamin keberadaan telur cacing. Infeksi parasit cacing digolongkan menjadi 3 kelas yaitu kelas ringan berkisar 0 - 500 EPG, kelas sedang berkisar 501 - 1000 EPG dan kelas berat apabila melebihi 1000 EPG (Junaidi et al., 2014). Infeksi telur cacing pada saluran pencernaan ternak dapat berakibat fatal karena dapat mengambil nutrisi, menghisap darah dan memakan jaringan tubuh yang akan berdampak pada penurunan bobot badan hingga kematian (Pradana et al., 2015). Herawati dan Winarso (2016) menambahkan infeksi telur cacing pada saluran pencernaan 
Tabel 3. Pengaruh Perbedaan Ketinggian Dataran terhadap Kandungan Telur Cacing Ayam Broiler yang Dipelihara pada Sistem Perkandangan Closed House

\begin{tabular}{lccccc}
\hline \multirow{2}{*}{ Perlakuan } & \multicolumn{5}{c}{ Ulangan } \\
\cline { 2 - 6 } & U1 & U2 & U3 & U4 & U5 \\
\hline T1 & Negatif & Negatif & Negatif & Negatif & Negatif \\
T2 & Negatif & Negatif & Negatif & Negatif & Negatif \\
T3 & Negatif & Negatif & Negatif & Negatif & Negatif \\
\hline
\end{tabular}

ternak akan mengakibatkan penurunan bobot badan, produktivitas hingga kematian. Keberadaan infeksi telur cacing dapat disebabkan oleh biosecurity kandang yang kurang baik dan kondisi ternak yang tidak sehat. Penerapan biosecurity yang sesuai standar akan mencegah infeksi yang dapat memberikan dampak buruk bagi ternak (Ardana, 2011).

\section{KESIMPULAN}

Hasil penelitian dapat disimpulkan bahwa perbedaan ketinggian dataran mempengaruhi ketebalan litter pada kandang closed house sedangkan telur cacing tidak ditemukan.

\section{UCAPAN TERIMAKASIH}

Terima kasih kepada Lembaga Penelitian dan Pengabdian kepada Masyarakat Universitas Diponegoro (LPPM UNDIP) atas fasilitasinya pada kegiatan Penelitian Dasar Direktorat Riset dan Pengabdian Masyarakat Direktorat Jenderal Riset dan Pengembangan Kementerian Riset, Teknologi, dan Pendidikan Tinggi dengan Nomor: 225-67/UN7.6.1/ PP/2020 tanggal Tanggal 20 Maret 2020.

\section{DAFTAR PUSTAKA}

Amrullah, M., B. I. Moeda, Tampoebolon dan B. W. Prasetyono. 2019. Kajian pengaruh proses fermentasi sekam padi amoniasi menggunakan Aspergillus Niger terhadap serat kasar, protein kasar, dan Total Digestible Nutrients. J. Pengembangan Penyuluhan Peternakan. 16 (29) : 25-31.

Ananda, R.R., E. Rosa dan G. D. Pratami. 2017. Studi nematoda pada ayam petelur (Gallus gallus) strain Isa Brown di peternakan mandiri Kelurahan Tegal Sari, Kecamatan Gading Rejo, Kab. Pringsewu, Lampung. J. Biologi Eksperimen dan Keragaman Hayati. 4 (2): 23-27.

Ardana, I. B. K. 2011. Strategi pencegahan penyakit inefeksius pada peternakan broiler berbasis laboratorium. Buletin Veteriner Udayana. 3 (1) : 51-59.

Dewanti, A. C., P. E. Santoso dan K. Nova. 2014. Pengaruh berbagai jenis bahan litter terhadap respon fisiologis broiler fase finisher di closed house. J. Ilmiah Peternakan Terpadu. 2 (3) : 81-87.

Dharmawan, R., H. S. Prayogi dn V. M. A. Nugiartiningsih. 2016. Penampilan produksi ayam pedaging yang dipelihara pada lantai atas dan lantai bawah. J. Ilmu - Ilmu Peternakan. 26 (3): $27-37$.

Endraswati, A., L. D. Mahfudz dan T. A. Sarjana. 2019. Kontribusi faktor klimat di luar kandang terhadap perubahan mikroklimat closed house dengan panjang berbeda pada periode brooder di musim kemarau. J. Agripet. 19 (1) : 59 - 67. DOI: https://doi.org/10.17969/ agripet.v19i1.13918

Fatmaningsih, R., Riyanti dan K. Nova. 2016. Performa ayam pedaging pada system Brooding konvensional dan Thermos. J. 
Ilmiah Peternakan Terpadu. 4 (3) :222229.

Herawati dan D. Winarso. 2016. Pengaruh pemberian sari kunyit (Curcuma domestica Val.) dalam air minum terhadap jumlah telur cacing Ascaridia galli pada ayam broiler. J. Riset Agribisnis dan Peternakan. 1 (2) : 1324.

Ibrahim, S. dan Allaily. 2012. Pengaruh berbagai bahan litter terhadap konsentrasi ammonia udara ambient kandang dan performan ayam broiler. J. Agripet. 12 (1) : $47-52$.

Junaidi, M., P. Sambodo dan D. Nurhayati. 2014. Pravelansi nematode pada sapi Bali di Kabupaten Manokwari. J. Sain Veteriner. 32 (2) : 168-176.

Loliwu, Y. A. dan I. Thalib. 2012. Prevalensi penyakit cacing pada ayam buras di desa Taende dan Tomata kecamatan Mori Atas kabupaten Morowali. J. Agropet. 9 (1) : 69-83.

Marang, E. A. F., L. D. Mahfudz, T. A. Sarjana dan S. Setyaningrum. 2019. Kualitas dan kadar amonia litter akibat penambahan sinbiotik dalam ransum ayam broiler. J. Peternakan Indonesia. 21 (3) : 303-310.

Marom, A. T., U. Kalsum dan U. Ali. 2017. Evaluasi performans broiler pada sistem kandang close house dan open house dengan altitude berbeda. Dinamika Rekasatwa. 2 (2) : 1-10.

Muharlien, Achmanu dan R. Rachmawati. 2011. Meningkatkan produksi ayam pedaging melalui pengaturan proporsi sekam, pasir dan kapur sebagai litter. J. Ternak Tropika. 12 (1) : 38-45.

Moenek, D. Y. J. A. dan A. B. Oematan. 2017. Endoparasit pada usus ayam kampung(Gallus domesticus). J. Kajian Veteriner. 8 (2) : 84-90.

Najibulloh, M., N. Ulupi dan Salundik. 2020. Pengaruh daur ulang litter terhadap kualitas litter dan udara dalam pemeliharaan broiler. Livestock and Animal Research. 18 (2) : 107-115.

Olivia, M., M. Hartono dan V. Wanniatie. 2015. Pengaruh jenis bahan litter terhadap gambaran darah broiler yang dipelihara di closed house. J. Ilmiah Peternakan Terpadu. 3 (1) : 23-28.

Pradana, D. P., T. Haryono dan R. Ambarwati. 2015. Identifikasi cacing endoparasit pada feses ayam pedaging dan ayam petelur. J. LenteraBio. 4 (2) : 119-123.

Qurniawan, A., I. I. Arief dan R. Afnan. 2016. Performans produksi ayam pedaging pada lingkungan pemeliharaan dengan ketinggian yang berbeda di Sulawesi Selatan. J. Veteriner. 17 (4) : $622-633$.

Resnhaleksmana, E. 2014. Prevalensi nematoda usus golongan Soil Transmitted Helminthes (STH) pada peternak di lingkungan Gatep Kelurahan Ampenan Selatan. Media Bina Ilmiah. 8 (5) : 45-50.

Saputra, M. R., S.Kismiati dan T. A. Sarjana. 2020. Perubahan mikroklimatik amonia dan kondisi litter ayam broiler periode starter akibat panjang kandang yang berbeda. J. Sains Peternakan. 18 (1) : 7-14.

Saputra, T. R., K. Nova dan D. Septinova. 2015. Pengaruh penggunaan berbagai jenis litter terhadap bobot hidup, karkas, giblet, dan lemak abdominal broiler fase finisher di closed house. J. Ilmiah Peternakan Terpadu. 3 (1) : 3844.

Silaban, R., R. Febriansyah dan S. Pulungan. 2018. Identifikasi endoparasit nematoda pada feses ayam broiler di peternakan Submitra Indojaya Agrinusa Desa Pudun Jae. J. Grahatani. 4 (1) : 570579.

Wahyudi, W. A., H. Afriani dan N. Idris. 2010. Evaluasi adopsi teknologi peternakan ayam broiler di kecamatan Sungai Gelam kabupaten muaro Jambi. J. Penelitian Universitas Riau Seri Humonaria. 12 (2) : 23-28. 